\title{
THE EFFECT OF SOOT LAYER ON TRANSMISSION LOSSES AND NOISE REDUCTION FACTOR OF A DIESEL PARTICULATE FILTER UNIT
}

\section{Suleiman Abu-Ein}

Department of Mechanical Engineering, Faculty of Engineering

Technology, PO Box 15008, E-mail: drsuleiman@fet.edu.jo

Al Balqa' Applied University, Amman - Jordan

(Received April 6, 2008 Accepted June 2, 2008)

Diesel particulate filters are good tools in gas emission reduction (and also particulate matters) in addition to noise reduction. In this paper the effect of soot layer on both transmission losses and noise reduction factor is studied. It is clear that for both hot and cold conditions the transmission losses with the existence of soot layer are greater than those without soot layer existence, since the soot layer is considered here as a new medium or a new component that increases sound absorption and consequently increases the sound transmission losses.

KEYWORDS: soot layer, transmission losses, noise reduction factor, diesel particulate filters, wall resistance, and porous media.

\begin{tabular}{|c|c|c|c|}
\hline \multicolumn{4}{|c|}{ NOMENCLATURE } \\
\hline$A$ & Area or cross sectional area $\left[\mathrm{m}^{2}\right]$ & $S p$ & surface area of the particle $\left[\mathrm{m}^{2}\right]$ \\
\hline$C$ & speed of sound $[\mathrm{m} / \mathrm{s}]$ & $T$ & temperature[k] \\
\hline$D$ & diameter $[\mathrm{m}]$ & $T L$ & transmission losses $[\mathrm{dB}]$ \\
\hline$D_{p}$ & effective particle & Vo & volume of enclosure $\left[\mathrm{m}^{3}\right]$ \\
\hline & diameter $[\mathrm{m}]$ & $W_{i}$ & incident sound power [W] \\
\hline $\mathrm{DPF}$ & diesel particulate filter & $W_{t}$ & transmitted sound power [W] \\
\hline$d$ & diameter of cavity[m] & $w$ & frequency[1/s] \\
\hline $\mathrm{dB}$ & decibel & $\alpha$ & sound absorption \\
\hline $\mathrm{Hz}$ & hertz & & coefficient.[ Sabins] \\
\hline$h_{t}$ & wall thickness[m] & $\dot{\alpha}$ & average sound absorption \\
\hline$L$ & Length $[\mathrm{m}]$ & & coefficient [Sabins] \\
\hline$L p$ & sound pressure level [dB] & $\Delta P$ & pressure drop [Pa] \\
\hline$M_{j}$ & Mach number & $\rho$ & density $\left[\mathrm{kg} / \mathrm{m}^{3}\right]$ \\
\hline$P$ & pressure $[\mathrm{Pa}]$ & $\mu$ & viscosity $\left[\mathrm{Ns} / \mathrm{m}^{2}\right]$ \\
\hline$P_{0}$ & ambient pressure or reference & $\sigma$ & permeability[ Darcy] or $\left[\mathrm{m}^{2}\right]$ \\
\hline & pressure $[\mathrm{Pa}]$ & $R_{1}$ & viscous flow resistance \\
\hline PM & particulate matter. & & {$\left[\mathrm{Ns} / \mathrm{m}^{3}\right]$} \\
\hline$Q$ & volumetric flow rate $\left[\mathrm{m}^{3} / \mathrm{s}\right]$ & $R_{2}$ & second order flow resistance \\
\hline $\operatorname{Re}$ & Reynold's number & & {$\left[\mathrm{Ns}^{2} / \mathrm{m}^{4}\right]$} \\
\hline$R_{H}$ or $R_{h}$ & hydraulic radius[m] & $n$ & an odd integer \\
\hline
\end{tabular}




\section{INTRODUCTION}

Diesel Particulate Filter (DPF) is a superior system in the reduction of particulate matters, because it can reduce about $70 \%$ of the particulate matters (PM). It contains a large number of thin tubes or cavities with a diameter of about (1-2 mm), and (0.15-0.5 $\mathrm{m}$ ) length, see Figure (1) (Appendix 1). There are many types of DPFs (see appendix (1)), such as: electric heater type, burner type (ceramic filter), and fuel additive type; the latter type is a honey-comb ceramic one. The honey-comb type constitutes an additive supply and an electronic system. In this type, Fe is used as an additive, whereby iron oxide is formed which reacts with carbon and is then converted to iron. When a certain temperature is reached, the $\mathrm{O}_{2}$ formed around the iron oxide reacts with the Particulate Matter (PM) so that these particles could be regenerated in the existence of $\mathrm{O}_{2}$ of the catalyst. For many diesel engines, the exhaust gas temperature is insufficient to regenerate the filter.

Diesel particulate filters are also very sensitive to exhaust gas temperatures and fuel sulfur content which affect the performance of the DPF system. Other factors affecting the DPF performance are its dimensions, soot layer thickness and heat losses. For most continuously regenerating catalyzed particulate filters to work properly, an engine should operate at around $300^{\circ} \mathrm{C}$ for 30 percent of the duty cycle or for 30 minutes. Some other types of diesel particulate filters require an average exhaust temperature of at least $270^{\circ} \mathrm{C}$ for 40 percent of the engine duty cycle, (Washington State University extension in the energy program).

Exhaust gas temperatures are highly application dependent. Excessive heat loss in the exhaust system can cause lower exhaust gas temperatures, which can over-size engines that are operated low on their torque/power curves. Although many diesel applications generate sufficient exhaust gas temperatures for successful DPF operations, device manufacturers and regulators recommend that certain vehicle applications are equipped with data loggers to continuously monitor exhaust back pressure and temperature. Once it is determined that sufficient exhaust gas temperatures exist for filter regeneration, the monitoring can be stopped. Fuel sulfur content also affects the performance of passive DPFs [18], and (Washington State University extension in the energy program).

DPF operation is affected by the existence of soot layer, because as the DPF works, a soot layer takes place inside the DPF.

For clean filters without soot loading, DPFs' wall resistance, $R_{w}$, can be written as in [1]:

$$
R_{w}=\frac{\mu_{w} h_{t}}{\sigma_{w}}
$$

While with soot loading (not clean) of the DPF unit the wall resistance can be written as in [1]:

$$
R_{w}=\mu_{w}\left(\frac{h_{t}}{\sigma_{w}}+\frac{h_{\text {soot }}}{\sigma_{\text {soot }}}\right)
$$

where

$\sigma_{\text {soot }}=1.5 \times 10^{-14}$ (permeability with soot), $h_{\text {soot }}=1 / 10 h_{t}, h_{t}$ : is the wall thickness[2]. 


\section{Transmission losses (TL)}

Transmission losses are defined by the difference between the sound power incident on the DPF unit and that transmitted downstream into an anechoic termination. It can be given as in [1], and [9]:

$$
T L=10 \log \left(W_{i} / W_{t}\right)
$$

where: $W_{i}$ : is the incident power in watts, $W_{t}$ : is the transmitted power in watts.

For DPF unit transmission losses can be given as in [1]:

$$
T L=20 \log \left(0.5\left|T_{D P F}\right|\right)
$$

where

$\mathrm{T}_{\mathrm{DPF}}$ is the transformation matrix of the DPF unit.

\section{Noise Reduction Factor (NRF)}

Noise reduction factor is the difference in sound pressure levels LP at two arbitrary selected points in the exhaust pipe and in the tail pipe. It doesn't need or require an anechoic termination because it uses the standing wave pressures, [19].

Depending on the noise reduction factor's definition it can be given as in[1], and [7]:

$$
N R F=L P_{2}-L P_{1}=20 \log \frac{P_{2}}{P_{1}}
$$

$N R F$ is an efficient tool to distinguish different types of DPF and can be rewritten as in [1]:

$$
N R F=T L+10 \log \left(\frac{\alpha}{A}\right)
$$

where A: is the area of the partition. $\left(\mathrm{m}^{2}\right) ; T L$ : is the transmission loss; $\alpha$ : is the sound absorption factor.

\section{RESULTS AND DISCUSSION}

The effect of soot layer is significant on both sound transmission losses and noise reduction and as seen from results, TL and NRF increase with the existence of soot layer but the increase of this layer affects the DPF performance and hence a regenerating of the DPF unit is needed. Figures (1) through (4) represent TL of different types of DPF unit with no soot layer, under the case of hot condition and time harmonic variation only. It can be noticed from these figures that there is a good agreement in the behavior of TL against the frequency between the two studies; the present study and that of Allam[1], but there is some improvement for the proposed study because it takes into account the effect of transverse velocity. Hence, it showed more acoustic transmission losses and consequently more noise reduction.

Figure (1) represents the TL of different types of DPF against frequency with soot layer. It can be noticed that EX80:200/14 DPF type has a good property in terms of reducing transmission losses, but EX80:100/17 DPF type has less ability to do this. EX80: 200/14 has good properties and suitable dimensions compared with other DPF 
types; including low channel width, low permeability, high wall thickness, low porosity, and making high pressure drop.

Figure (2) shows the Noise Reduction Factor (NRF) against frequency for typical DPF unit, with soot layer and with no soot layer. It can be noticed from the figure that the noise reduction is proportional to frequency since it is proportional to transmission losses as shown in equation (6). From figure (2) it can be noticed that the values of noise reduction factor in the case of soot layer are higher than those with no soot layer, because the soot layer represents a new absorber for sound waves and hence causes more transmission losses and noise reduction.

Figures (3) through (8) show the TL versus frequency for the typical DPF unit and other types under hot conditions, time harmonic variation only and harmony in time and 2-D space cases; with soot layer and with no soot layer and for $\mathrm{M}=0.02$. From these figures, it can be noticed that the transmission losses with the existence of soot layer are higher than those with no soot layer for the above mentioned reasons. Figure (9) represents the transmission losses for different types of DPF unit against frequency, at $\mathrm{T}=1000^{\circ} \mathrm{C}$. From this figure it can be noticed that EX80:200/14 DPF type has the best property to make transmission losses, but EX80:100/17 DPF type has the lowest property to do this, because EX80:200/14 DPF unit has good specifications and dimensions (properties) which give it the ability to make more transmission losses and noise reduction.

Figures (10) and (11) represent the relation between the noise reduction factor and the frequency under the case of hot conditions $\left(\mathrm{T}=500^{\circ} \mathrm{C}\right.$ and $\left.\mathrm{T}=1000^{\circ} \mathrm{C}\right)$, respectively, with soot layer and with no soot layer. From these figures it can be seen that noise reduction values for the case with soot layer are higher than those with no soot layer for the reasons mentioned above.

Figure (12) illustrates values of transmission losses at two operating temperatures: $500^{\circ} \mathrm{C}$ and $1000{ }^{\circ} \mathrm{C}$. It can be noticed that the temperature plays a significant role affecting the transmission loss and hence, the noise reduction. The figure shows that transmission losses are increasing as the temperature increases, since values of these two quantities (TL and NRF) are increased as the temperature becomes higher. The reason for this is that as the temperature increases the regeneration of the filter becomes fast and more efficient. As a new soot layer is loaded; therefore more transmission losses in sound waves and more noise reduction occurs. Figure (13) compares values of transmission losses of the present study and those of Allam [1]. It is clear that values of transmission losses of the present study are higher than those of Allam [1].

\section{CONCLUSIONS}

- Both transmission losses and noise reduction factor for the diesel particulate filters are increasing as frequency increases.

- Transmission losses at the case of existing soot layer are higher than those with no soot layer.

- EX80:200/14 DPF unit type has the best capability of transmission losses, while EX80:100/17 DPF type has the lowest capability. 
- $\quad$ There is a good agreement between theoretical values of TL of the present study with those available in the literature and also with experimental one.

- The temperature has a significant effect on both transmission losses and noise reduction factor, as the temperature increase both of these quantities are increase.

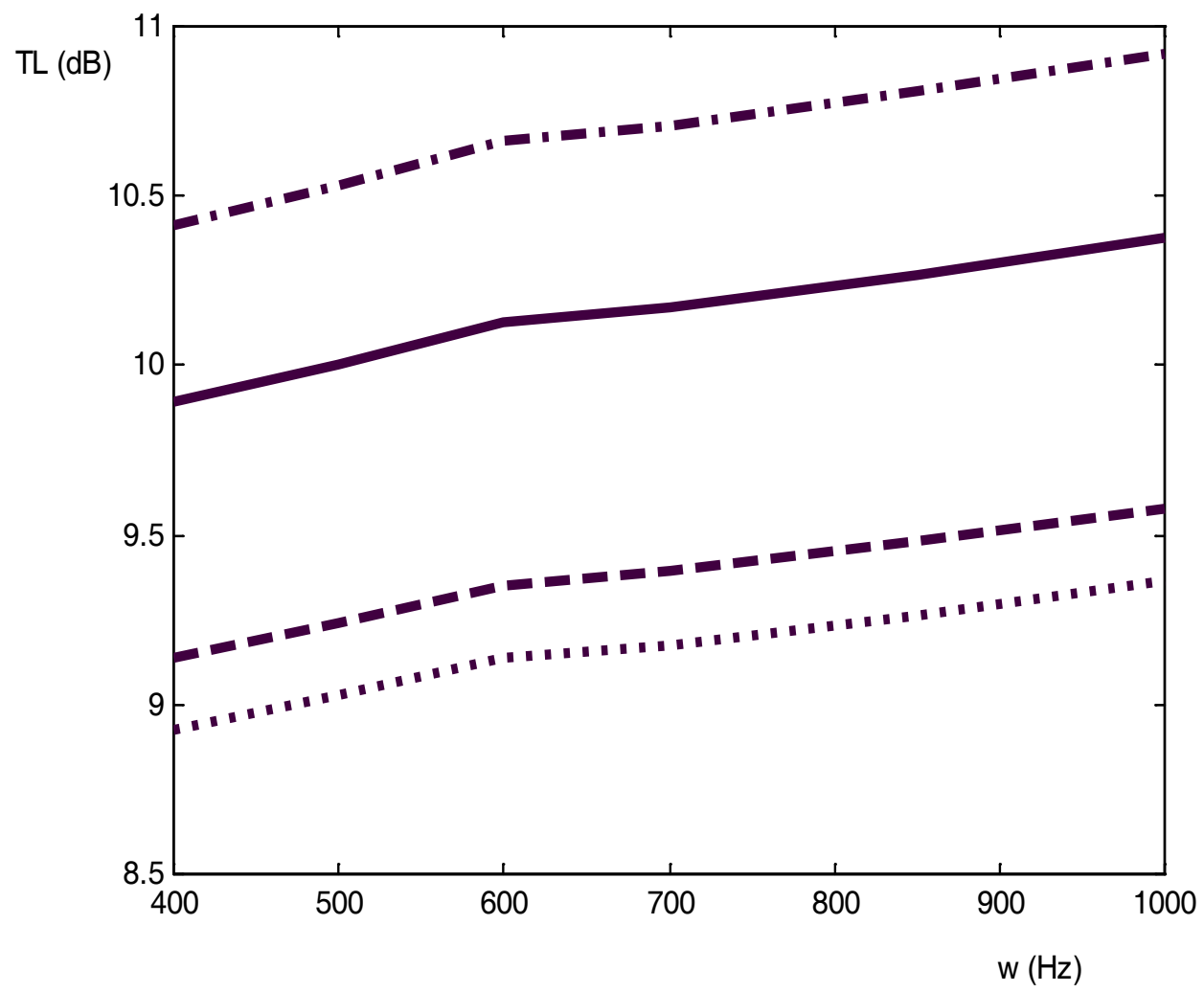

Figure (1): Transmission losses against frequeney, for RC: 200/12, -.-.-.for EX80: 200/14, -----for EX80:100/17, and.....for RC: 200/20 DPF unit type under the case of hot conditions $\left(\mathrm{T}=500^{\circ} \mathrm{C}\right)$, (With soot layer), and Mach=0.02. 


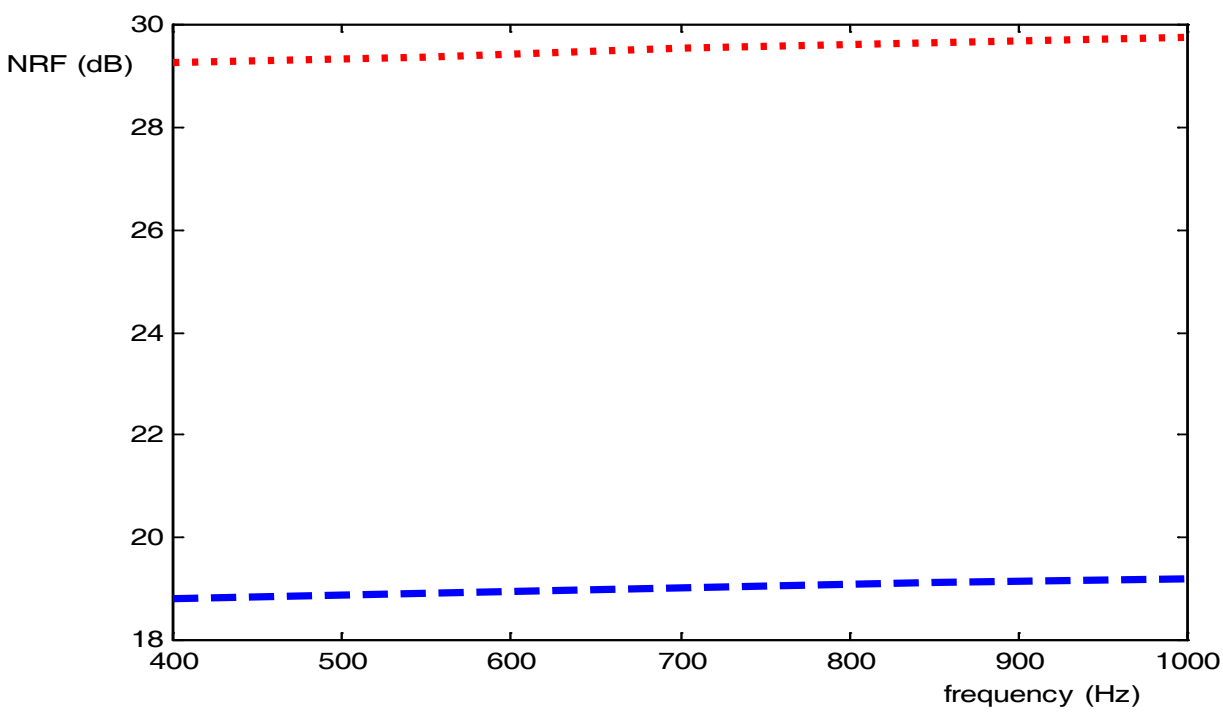

Figure (2): NRF against frequency for typical DPF under the case of hot conditions $\left(\mathrm{T}=500^{\circ} \mathrm{C}\right), \ldots \ldots \ldots$ (With soot layer), and ----- with no soot layer, and at Mach=0.02.

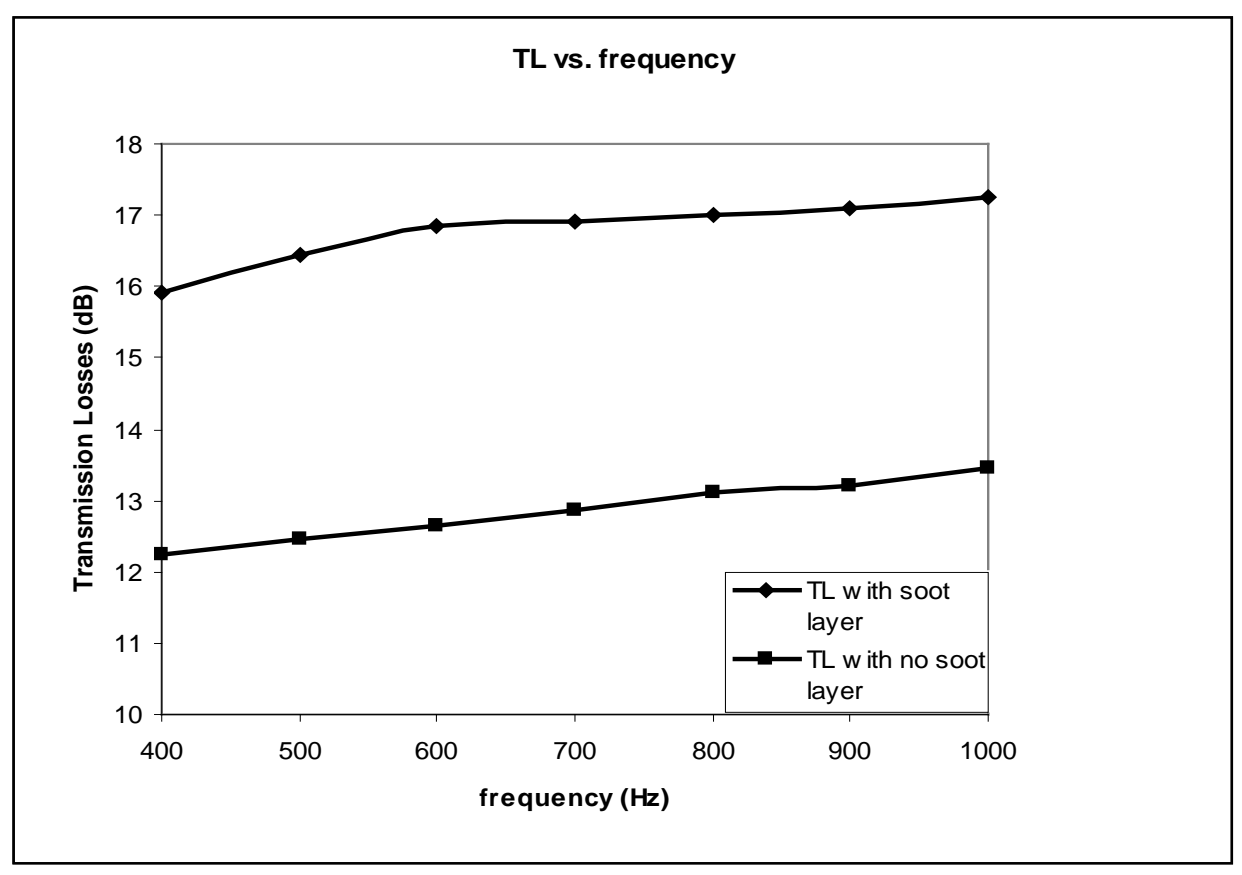

Figure (3): Transmission losses against frequency under the case of hot conditions $\left(\mathrm{T}=1000^{\circ} \mathrm{C}\right)$, and Mach $=0.02$. 


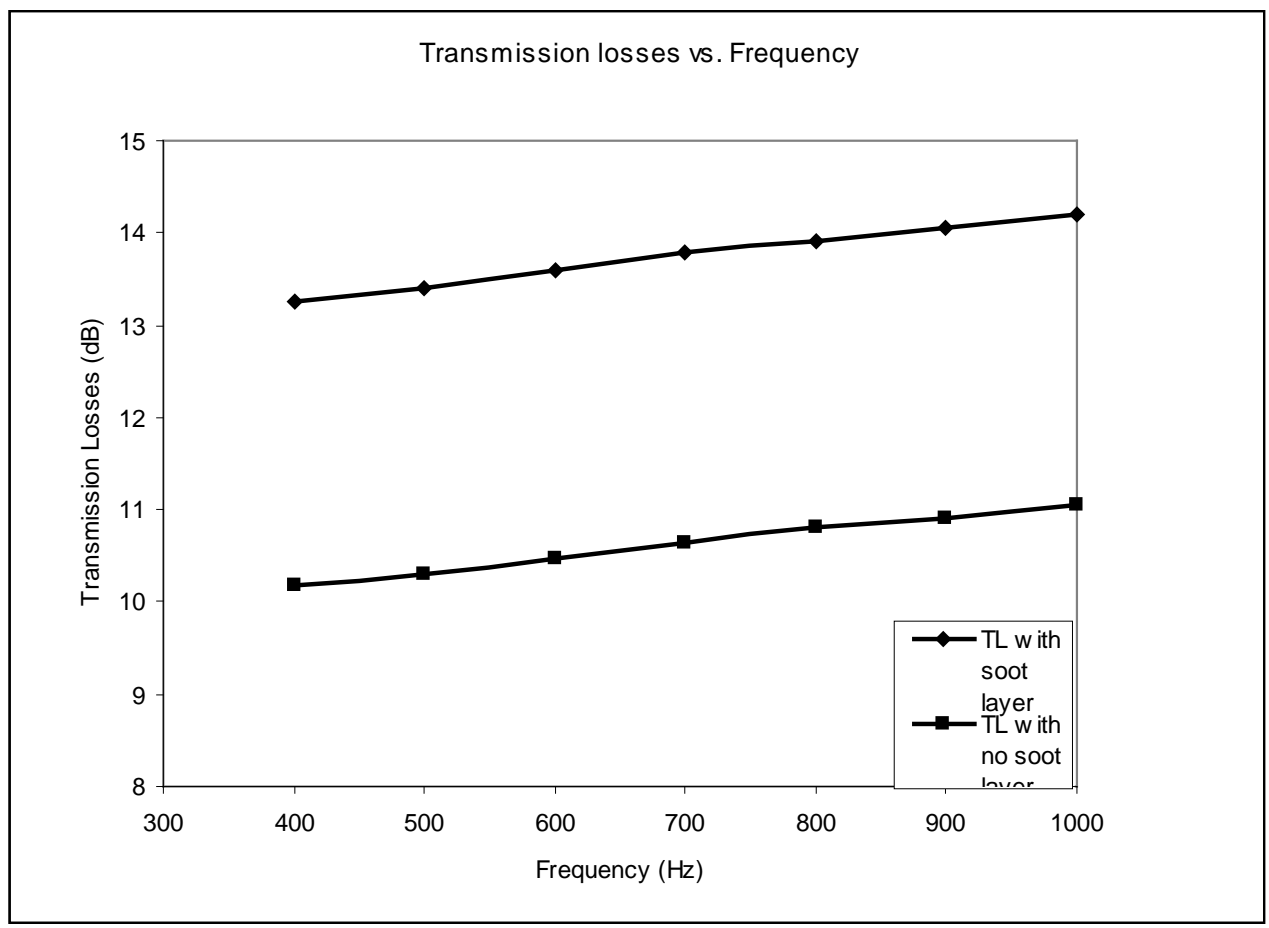

Figure (4): Transmission losses against frequency under the case of hot conditions $\left(\mathrm{T}=500{ }^{\circ} \mathrm{C}\right)$ for typical filter, Mach=0.02, and harmonic in time and 2-D space case.

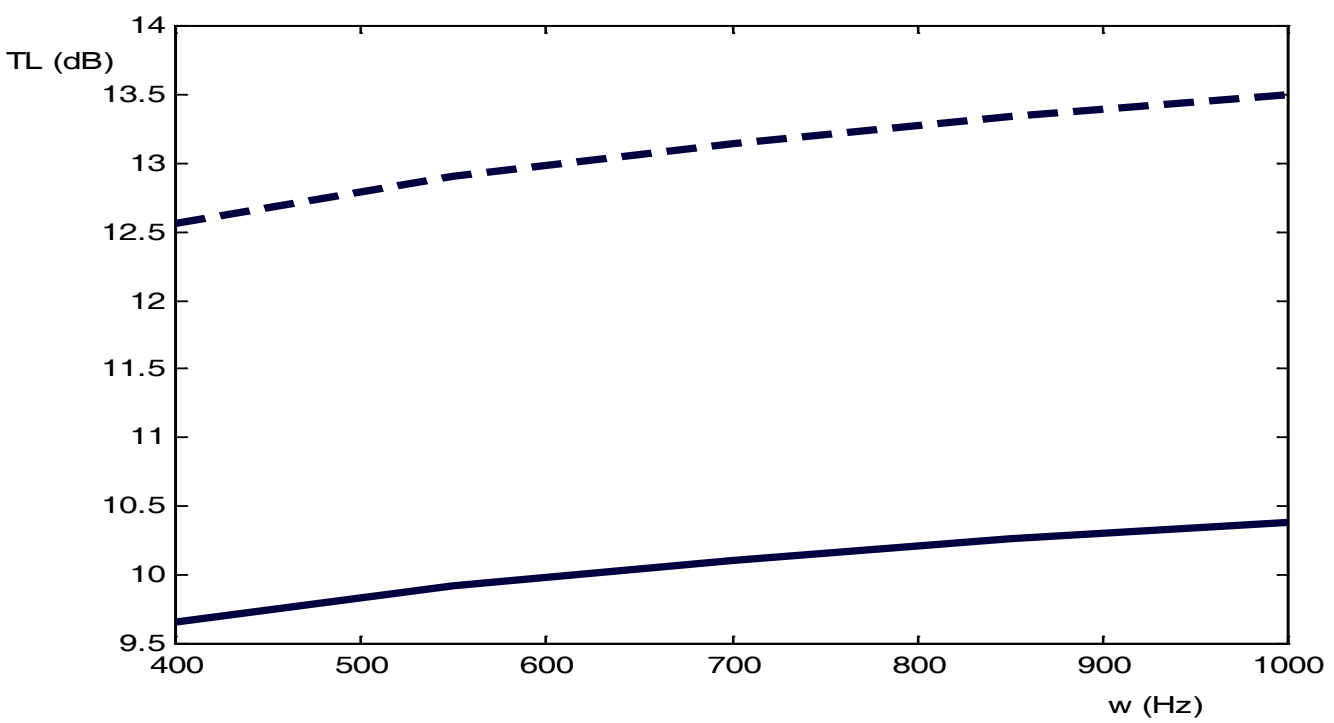

Figure (5): Transmission losses against frequency under the case of hot conditions $\left(\left(\mathrm{T}=500{ }^{\circ} \mathrm{C}\right)\right.$ for RC 200/12 filter type, ----- is for with soot layer, is for the case of no soot layer, Mach=0.02, and harmonic in time and 2-D space case. 
$\mathrm{TL}(\mathrm{dB})$

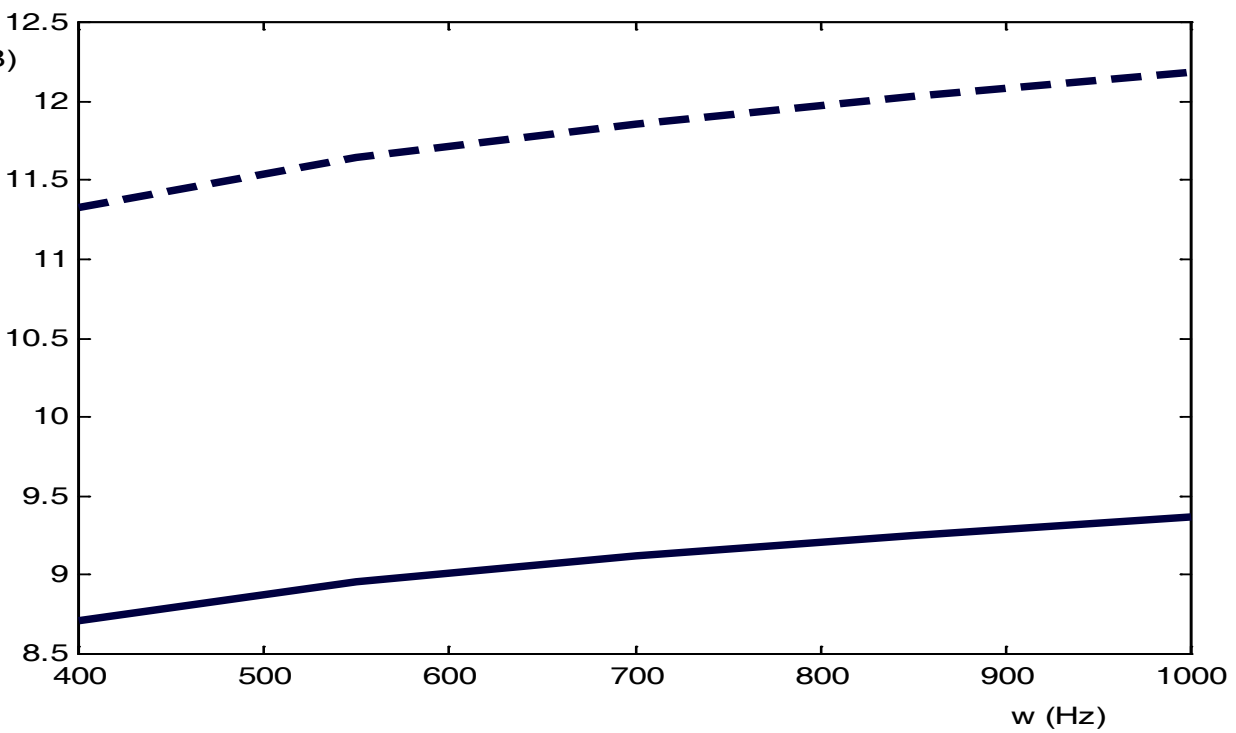

Figure (6): Transmission losses against frequency under the case of hot conditions for

RC 200/20 filter type, ----- for the case with soot layer is for the case of no soot layer, Mach=0.02, and harmonic in time and 2-D space case, $\left(\mathrm{T}=500^{\circ} \mathrm{C}\right)$.

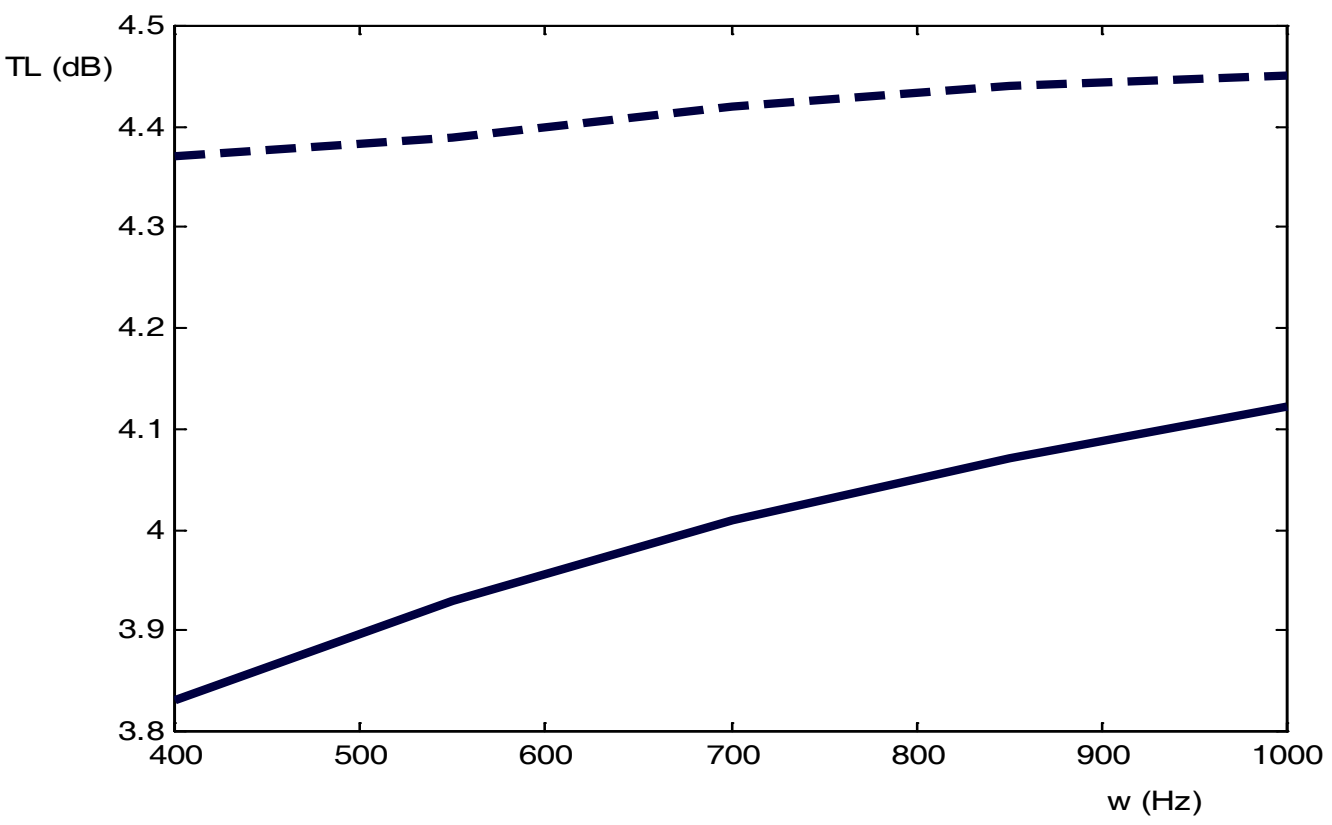

Figure (7): Transmission losses against frequency under the case of hot conditions for EX: 100/17 filter type, ----- for the case with soot layer, is for the case of no soot layer, Mach=0.02, and harmonic in time and 2-D space case, $\left(\mathrm{T}=500{ }^{\circ} \mathrm{C}\right)$. 


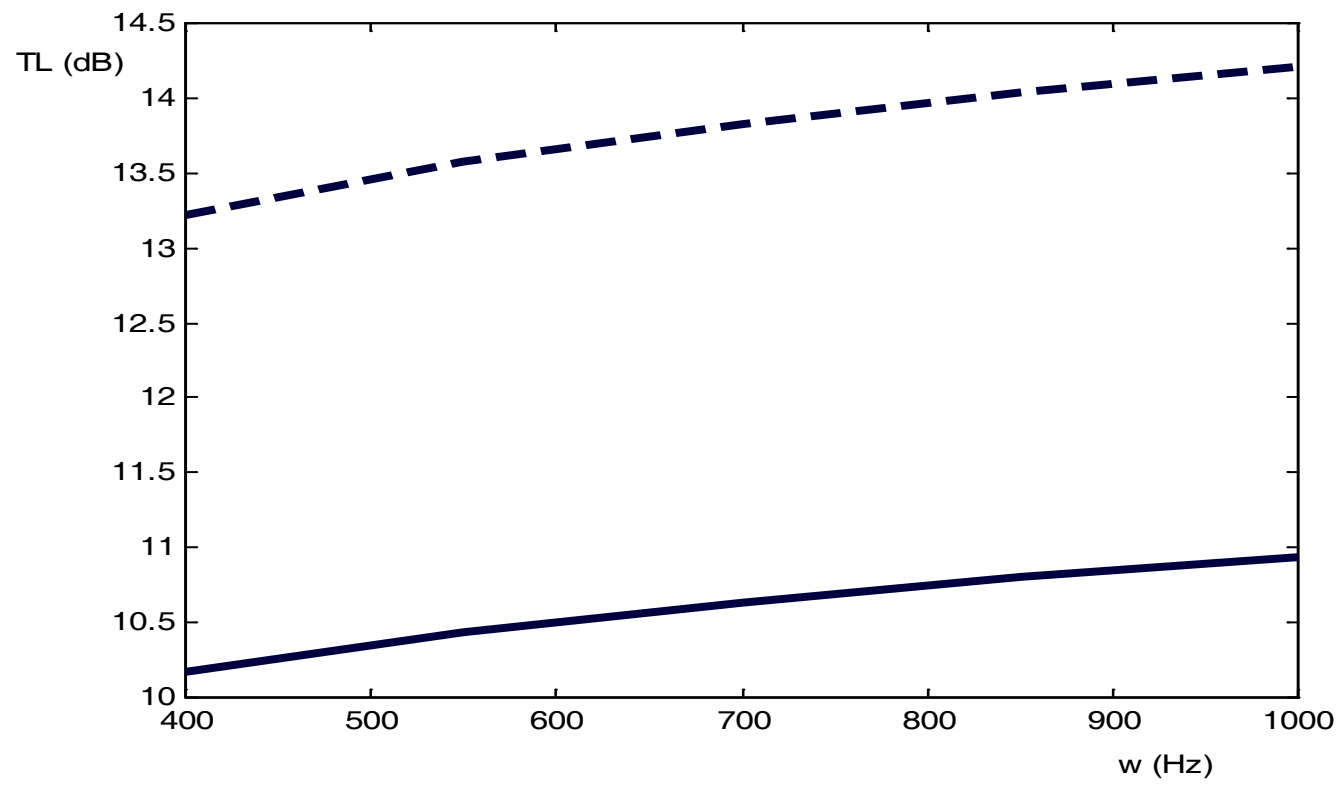

Figure (8): Transmission losses against frequency under the case of hot conditions for EX: 200/14 filter type, ----- for the case with soot layer, is for the case of no soot layer, Mach $=0.02$, and harmonic in time and 2-D space case, $\left(\mathrm{T}=500^{\circ} \mathrm{C}\right)$.

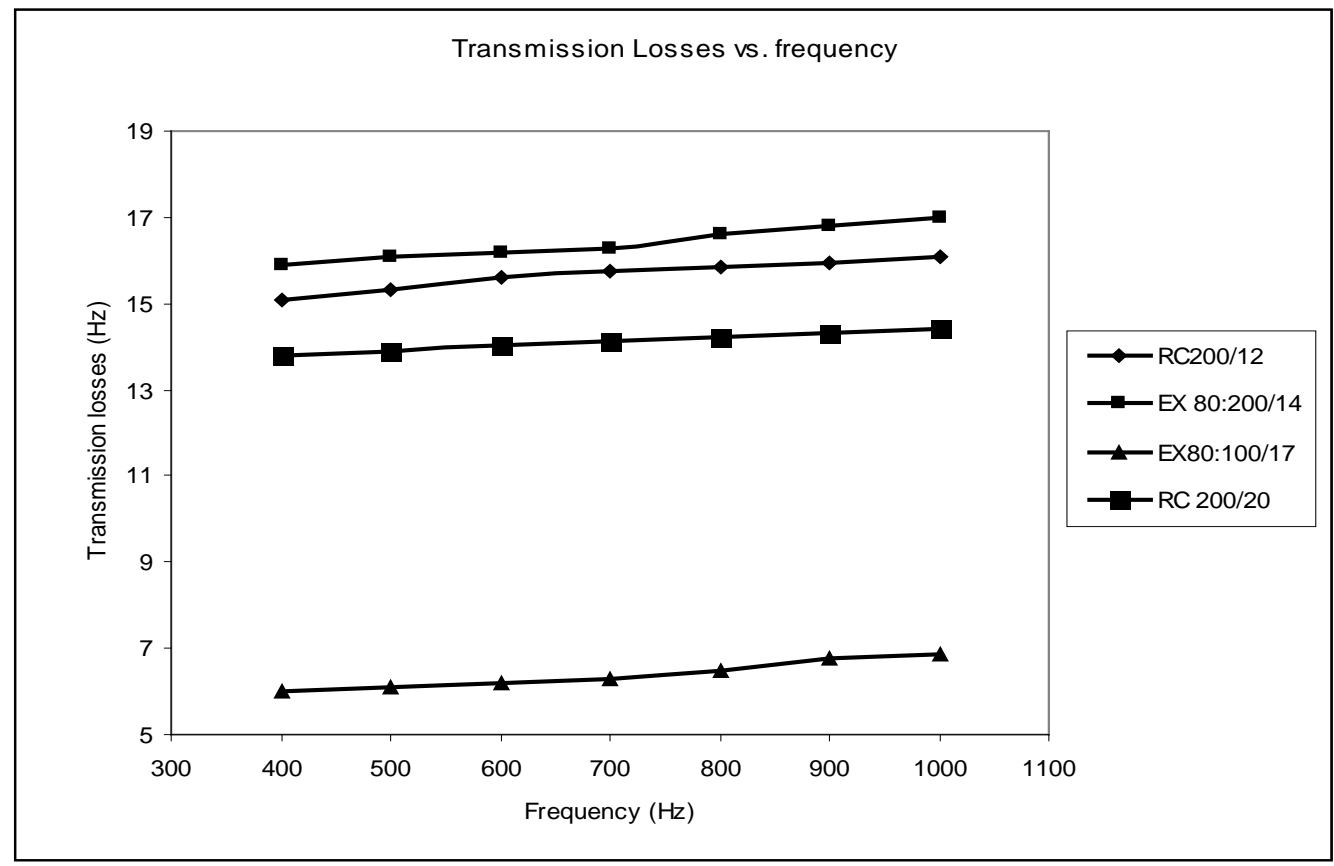

Figure (9): Transmission losses against frequency for different DPF unit types under the case of hot conditions $\mathrm{T}=1000{ }^{\circ} \mathrm{C}$, (With soot layer), and Mach=0.02. 


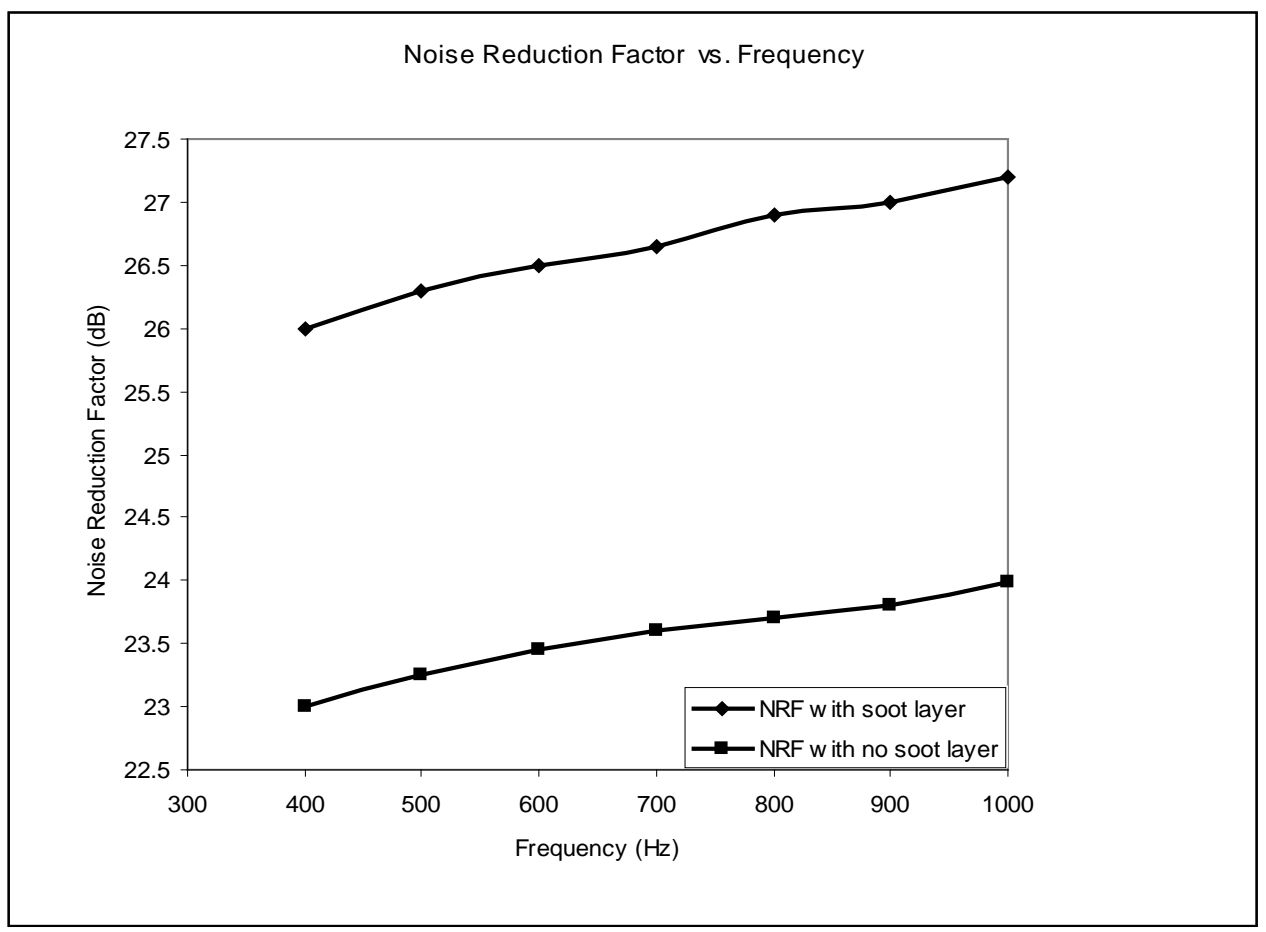

Figure (10): NRF against frequency for typical DPF under the case of hot conditions $\left(\mathrm{T}=500{ }^{\circ} \mathrm{C}\right)$, Mach $=0.02$, under the case of harmonic in time and 2-D space.

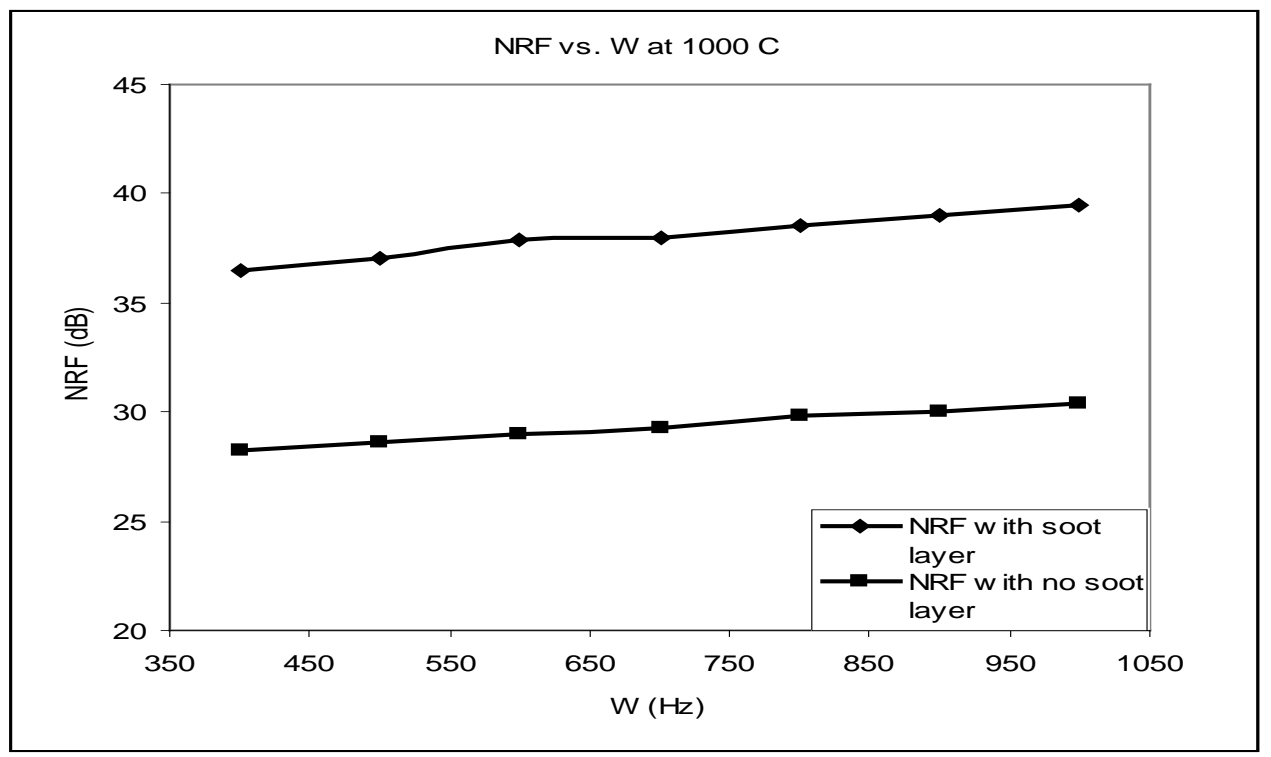

Figure (11): Noise reduction factor against frequency for typical DPF under the case of hot conditions $\left(\mathrm{T}=1000^{\circ} \mathrm{C}\right)$, Mach $=0.02$. 


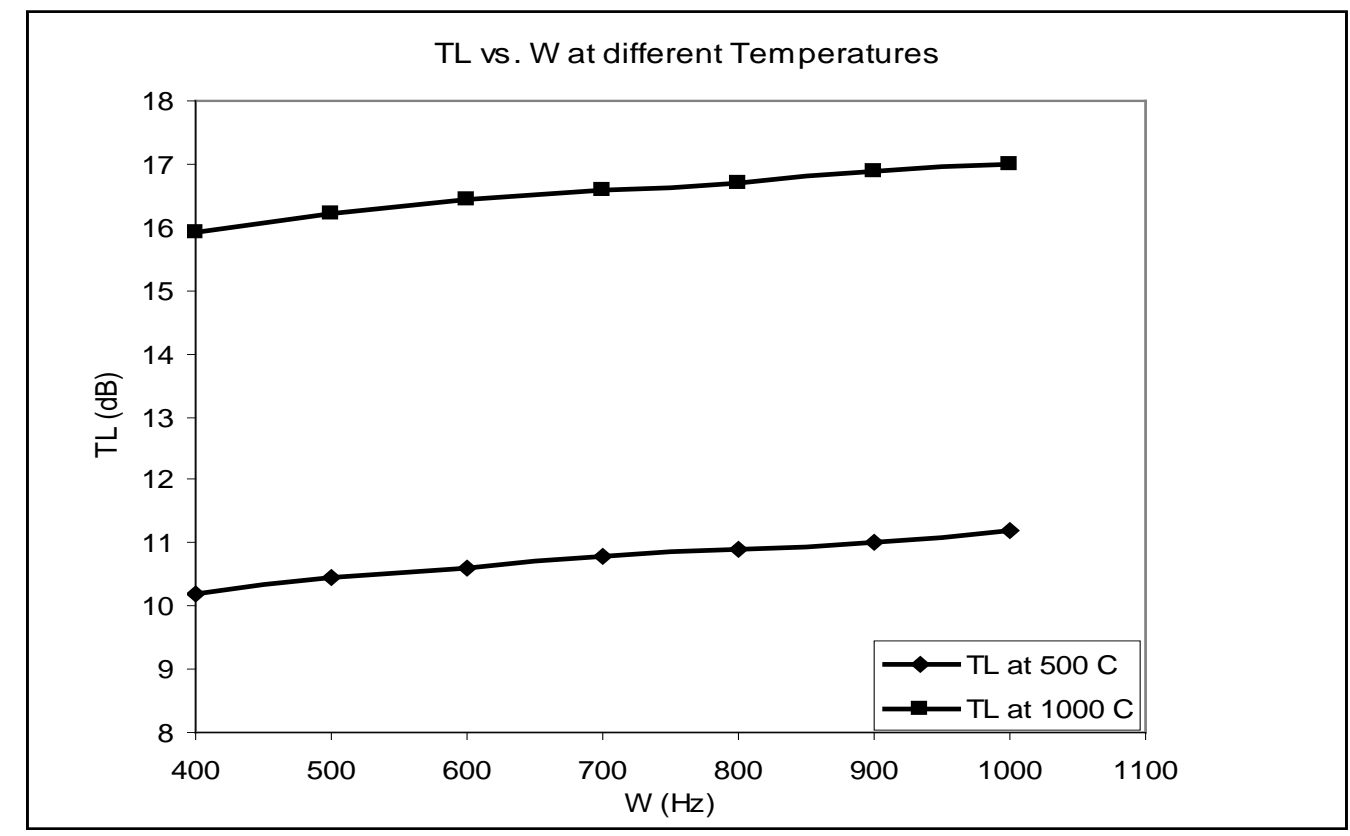

Figure (12): Transmission losses against frequency for typical DPF under the case of hot conditions $\left(\mathrm{T}=500^{\circ} \mathrm{C}\right)$, with soot layer, and $\mathrm{Mach}=0.02$.

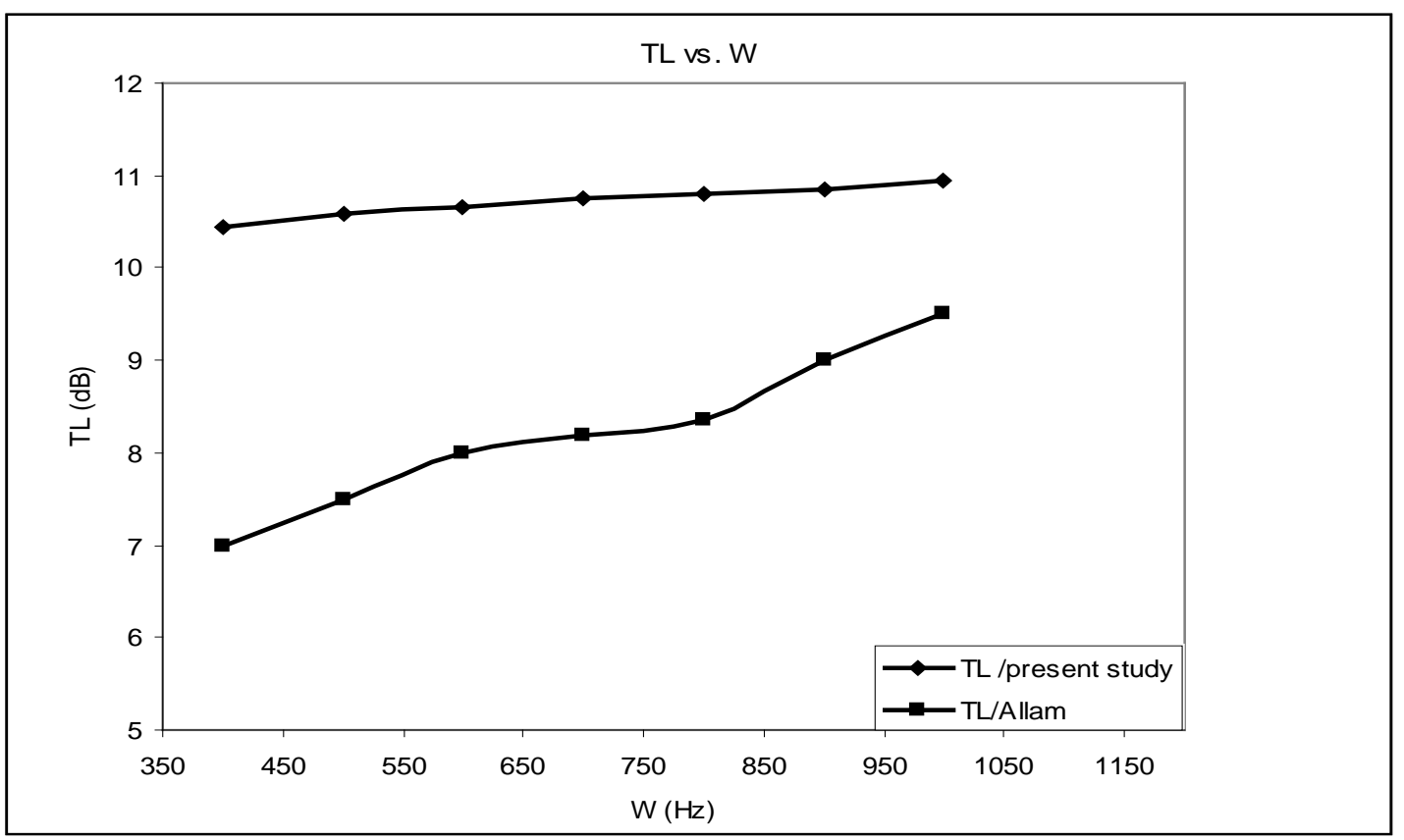

Figure (13) Comparing values of transmission losses of the present study with Allam [1] for EX80:200/14 DPF unit type at hot condition $\left(\mathrm{T}=500{ }^{\circ} \mathrm{C}\right)$, with soot layer. 


\section{Appendix 1}

Figure (1) Diesel Particulate Filter

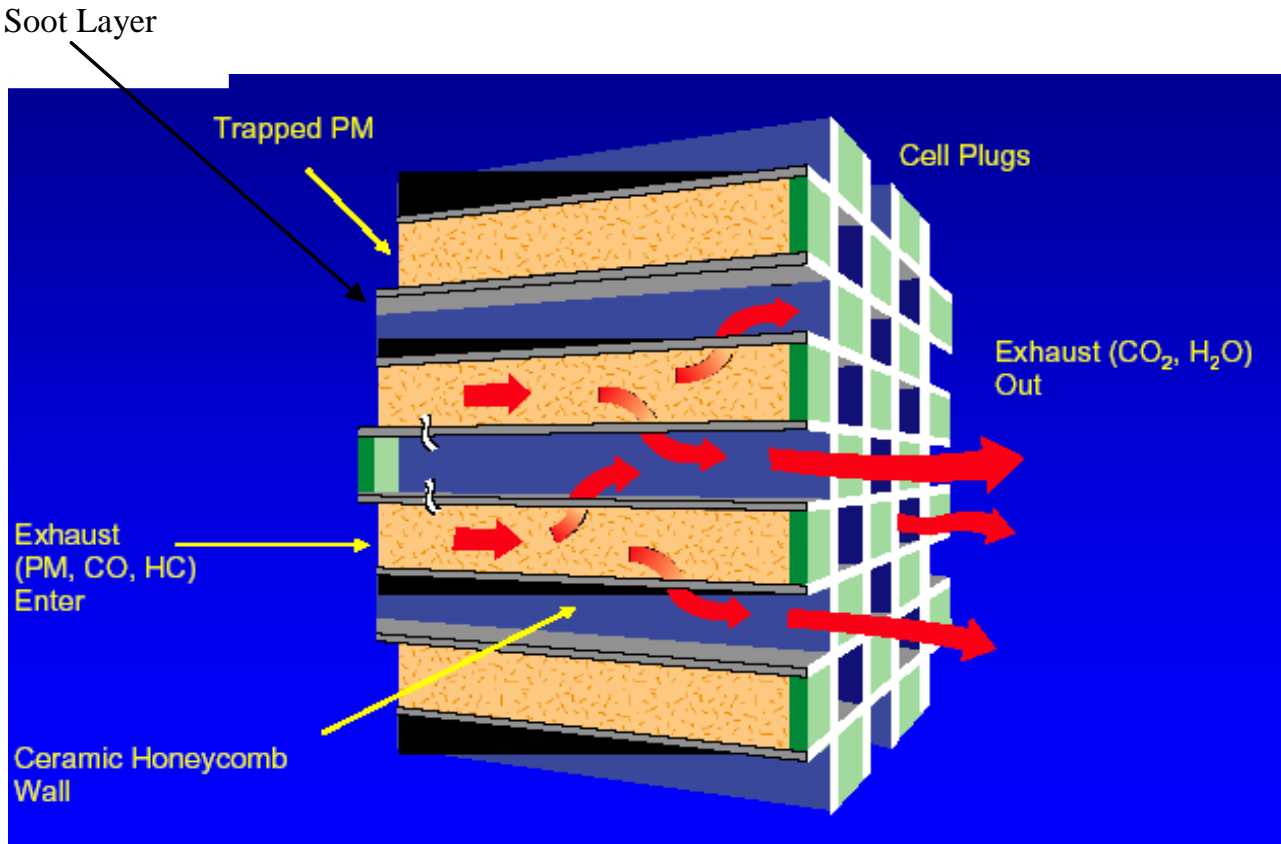

Table (1) Numerical values for different types of DPF units

Filter name channels $/ \mathrm{m}^{2}$ channels width wall thickness wall perme- $R$

$$
\begin{array}{llll}
n \times 10^{-5} & d_{h} \times 10^{3} \mathrm{~m} & h_{t} \times 10^{4} \mathrm{~m} & \begin{array}{c}
\text { ability } \sigma_{w} \times \\
10^{13} \mathrm{~m}^{2}
\end{array}
\end{array}
$$

$R 2$

\begin{tabular}{llllllr}
\hline RC: $200 / 12$ & 3.87 & 1.5 & 3.04 & 25 & 87. & RC \\
200/20 & 2.48 & 1.3 & 5.04 & 25 & 233.3 & 29.2 \\
EX80: $100 / 17$ & 1.55 & 2.11 & 4.3 & 2.5 & 199.8 & 41.56 \\
EX80: 200/14 & 3.10 & 1.44 & 3.55 & 2.5 & 184.1 & 30.92 \\
& & & & & & 39.2 \\
\hline
\end{tabular}

*Source: Dokumaci (2001), Allam (2002), Allam (2005), and Allam (2006).

\section{REFERENCES}

1. Allam, S., and Abom, M. (2006). Sound propagation in an array of narrow porous channels with application to diesel particulate filters, Journal of Sound and vibration, 291(3-5), 882-901.

2. Allam, S., and Abom, M. (2005). Acoustic modeling and testing of diesel particulate filters, Journal of Sound and Vibration 288 (1/2), 255-273. 
3. Astley, and Cummings, R.A. (1995).Wave propagation in catalytic converter: formulation of the problem and finite element scheme, Journal of Sound and vibration 188 (5), 635-657.

4. Ballagh, K.O. (2004). Accuracy of prediction methods for sound transmission loss. The $33^{\text {rd }}$ international congress and exposition on noise control engineering, Prague. Czech. August 22-25.

5. Boden, H., and Abom, M. (1995). Maximum sound power from in-duct sources with applications to fans. Journal of Sound and vibration, 187 (3), 543--550.

6. Boden, H., and Abom, M. (1990). Characteristics of acoustic two-port sources. Proceedings- international conference of noise control engineering, p 541.

7. Cummings, A. (1993). Sound propagation in narrow tubes of arbitrary crosssection. Journal of Sound and Vibration 162 (1), 27-42.

8. Chen, M., and Karen, S. (2003). A modeling approach to the design optimization of catalytic converters of I.C. engines. ASME, ICEF03.

9. Dokumaci, E. (1998). On transmission of sound in circular and rectangular narrow pipes with superimposed mean flow, Journal of sound and vibration 210 (3), 375-389.

10. Greevesm, G. (1977). Origins of hydrocarbon emission from diesel engines. SAE tans. 86.

11. Ih, J. G., Park, C.M., and Kim, H. J. (1996). A model for sound propagation in capillary ducts with mean flow, Journal of Sound and Vibration 190 (2), 163175.

12. Konstandopoulos, A.G., and Johnson, J.H. (1989). Wall-flow diesel particulate filters their pressure drop and collection efficiency, SAE paper No. 890405.

13. Kar, T., and Munjal, M. (2005). Generalized analysis of a muffler with any number of interacting ducts. Journal of Sound and Vibration 285, 585-596.

14. Martys, N. S. (2001). Improved approximation of the Brinkman equation using a lattice Boltzman method. Physics of fluids, volume 13, number 6 .

15. Mehdizadeh, O.Z., and Paraschivoiu, M. (2005). A three-dimensional finite elements approach for predicting the transmission losses in mufflers and silencers with no mean flow. Applied acoustics 66, 902-918.

16. Munt, R. (1990). Acoustic transmission properties of a jet pipe with subsonic jet flow. Journal of Sound and Vibration 142 (3), 413-436.

17. Muter, J. (1998). Predicting diesel particulate filters performance, diesel controls limited.

18. Qh, S.K., Baik, D.S., and Han, Y.C. (2002). Performance and exhaust gas characteristics on DPF trap. International journal of automotive technology. Vol. 3, no.3, pp. 111-115.

19. Seto, W. W. (1971). Schaum's outline of theory and problems of acoustics, Schaum's outline series, McGraw-hill book company, USA.

20. Silin, D., Korneev, V., and Goloshubi, G. (2003). Pressure diffusion waves in porous media. University of California, paper LBNL, 52536-EXT-Abs.

21. Tao, Z., and Seybert, A. (2001). A review of Current techniques for measuring muffler transmission loss. Society of automotive engineers, Inc. university of Kentucky. 03NVC-38. 
22. Tao, Z., Seybert, A., and Herrin, D. (2003). Measuring bulk properties of soundabsorbing materials using the two-source method. Society of automotive engineers, Inc. university of Kentucky. 03NVC-200.

23. To, C., and Doige, A. (1979). A transient testing technique for the determination of matrix parameters of acoustic systems, 1: theory and principles. Journal of Sound and Vibration 260 (2), 207-222.

24. Wijnant, Y.H., Hannink, M., and Boer, A. (2003). Application of viscothermal wave propagation theory for reduction of boundary layer induced noise. Euronoise, Naples, paper ID: 212/P.1.

25. Wu, T., Zhang, P., and Cheng, C.Y. (1998) Boundary element analysis of mufflers with an improved method for deriving the four-port parameters. Journal of Sound and Vibration, 217 (4) 767-779.

26. Yeh, L., Chang, Y., and Chiu, M. (2005). Shape optimal design on doublechamber mufflers using simulated annealing and a genetic algorithm. Turkish $\mathbf{J}$. Eng. Sci., 29, 207-224.

27. Yu, R., Shahed, S.M., (1981). Effects of injection timing and exhaust gas recirculation on emissions from a DI diesel engine. SAE paper no. 811234.

28. Zheng, H., and Keith, J. (2004). Ignition analysis of wall-flow monolith diesel particulate filters. Journal of catalysis today, 98, 403-412.

\section{دراسة تاثير طبقة السنج (SOOT LAYER) على مقار الفقان في الازعاج و تطبيق ذلك على فلتر ديزل حبيبي (DPF)}

في هذا البحث تم التعرض لتاثير طبقة السنج على مقدار الفقدان في الازعاج ( TRANSMISSION (LOSSES و معامل فقدان الازعاج (NRF) الصادر عن المحركات عبر الفلتز • حيث تم مقارنة قيم

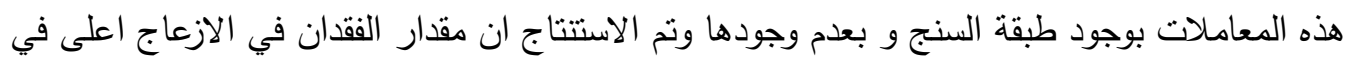

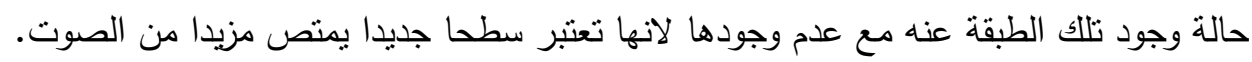

